\title{
ATMOSPHERIC DEPOSITION OF INORGANIC NITROGEN IN Grand Teton National Park: DETERMING BIOLOGICAL EFFECTS ON ALGAL COMMUNITIES IN ALPINE LAKES
}

\author{
SARAH A. SPAULDING $\uparrow$ MEGAN OTU $\uparrow$ UNIVERSITY OF COLORADO $\uparrow$ BOULDER \\ ALEXANDER P. WOLFE $\downarrow$ UNIVERSITY OF ALBERTA $\downarrow$ EDMONTON \\ JILL BARON $\downarrow$ COLORADO STATE UNIVERSITY $\downarrow$ FORT COLLINS
}

\begin{abstract}
$\uparrow \quad$ ABSTRACT
Sediment records from several high alpine lakes in the Grand Teton National Park (GRTE), Wyoming were examined for stable isotopic signatures $\delta^{15} \mathrm{~N}$ and diatom community composition because atmospheric deposition of reactive nitrogen $(\mathrm{Nr})$ is known to be altering ecosystem functioning in other lakes of the Rocky Mountain Range. Alpine lakes exposed to greater $\mathrm{Nr}$ impacts in Colorado have higher $\mathrm{N}: \mathrm{P}$ ratios in the water column, indicating an excess of N, thus GRTE sites were selected across a range of $\mathrm{N}: \mathrm{P}$ values, spanning measures indicative of nitrogen to phosphorus limitation. Sediment cores were analyzed for diatom relative abundances, concentrations of carbon, nitrogen and phosphorus, and stable isotopic signatures of $\delta^{13} \mathrm{C}$ and $\delta^{15} \mathrm{~N}$. Every sediment record showed progressive $\delta^{15} \mathrm{~N}$ depletion, evidence of increasing $\mathrm{Nr}$ deposition during the past forty years. In the GRTE, benthic flora dominated the community composition without changes to the fossil diatom taxonomy, a response atypical of other $\mathrm{Nr}$ impacted sites in the Rocky Mountain Range that have exhibited a marked shift towards nitrophilous planktonic diatoms Asterionella formosa and Fragilaria crotonensis. The suite of GRTE lacustrine sediment records exhibited a continuum of increasing nutrient enrichment from low to high $\mathrm{N}: \mathrm{P}$ ratios, suggesting that lakes sensitive to $\mathrm{Nr}$ enrichment exhibit elevated ratios of $\mathrm{N}: \mathrm{P}$. The long-term impact of $\mathrm{Nr}$ deposition has not reached a critical threshold, but monitoring of the GRTE lakes needs to
\end{abstract}

incorporate assessment of the $\mathrm{N}: \mathrm{P}$ ratios in advance of greater ecological impacts.

\section{$\downarrow \quad$ INTRODUCTION}

In western North America, the atmospheric deposition of reactive nitrogen (Nr), primarily as nitrate and ammonium, results in specific changes in surface water chemistry that shift the species composition of aquatic biota (Burns 2003, Fenn et al. 2003, Porter and Johnson 2007). The northern hemisphere is known to receive from 4 to 16 times more $\mathrm{Nr}$ through snow, rain and dry deposition than pre-industrial measures (Holland et al. 2000). In nutrient poor lakes of the northern hemisphere, including the Rocky Mountains, algae have historically been limited by nitrogen $(\mathrm{N})$ and respond to increases in concentration with community and ecosystem level change (Baron et al. 2000, Lafrancois et al. 2004, Nydick et al. 2004, Saros et al. 2003, Bergstrom 2010). Recent work indicates that persistent atmospheric deposition of $\mathrm{Nr}$, resulting in $\mathrm{N}$ saturation, has shifted the overall lake nutrient status to phosphorus (P) limitation in Colorado high elevation lakes (Elser et al. 2009). The eutrophication of lakes by deposition of atmospheric $\mathrm{Nr}$ is of great concern in the west, particularly in regard to the higher degree of $\mathrm{N}$ limitation in high elevation lakes. We lack, however, an understanding of both the degree of impact and the chronology of atmospheric deposition in the majority of the most sensitive areas of western North America. 
High elevation lakes in western North America are particularly vulnerable to acidification and eutrophication from inputs of nitrogen through atmospheric deposition (Seastedt et al. 2004, Baron et al. forthcoming). High elevation lakes are typically positioned within watersheds of resistant bedrock and poorly developed soils. As a result, the lakes are low in alkalinity and sensitive to acidification during the spring pulse of ions. Mountains receive large amounts of precipitation as snow, and when the snow melts in the spring it delivers an accumulated pulse of atmospheric pollutants (Williams et al. 1997, Williams and Tonnessen 2000). Ion concentrations in precipitation at high elevation sites deserve further examination (Nanus 2003) because nitrogen loads in the Rocky Mountains of Colorado and southern Wyoming have increased since the 1980s (Burns 2003). Lakes in the Grand Teton National Park (GRTE) were characterized and ranked based on sensitivity to acidification due to atmospheric deposition (Nanus 2005). In that study, thirty six percent of lakes in the park were predicted to be sensitive to acidification from atmospheric deposition of nitrogen and sulfur.

A coherent signal of depleted $\delta^{15} \mathrm{~N}$ values in precipitation is evident across western North America (Wolfe et al. forthcoming) and across much of the northern hemisphere (Wolfe et al. forthcoming). Stable isotopic signatures of $\delta^{18} \mathrm{O}$ and $\delta^{15} \mathrm{~N}$ in snowfall were depleted in four western parks, particularly in the most northerly GRTE site (Nanus et al. 2008). In the nearby Wind River Mountains, an ice core from the Upper Freemont Glacier showed a pattern of $\delta^{15} \mathrm{Nno}_{3}{ }^{-}$depletion (-5.9 to $-3.2 \%$ ) and increased $\mathrm{NO}_{3}{ }^{-}$concentrations, following the NADP data trend (Naftz et al. 2011). The same trend was seen in the Summit Greenland ice core with rising $\mathrm{NO}_{3}{ }^{-}$concentrations and $\delta^{15} \mathrm{NnO}_{3}{ }^{-}$depletion of up to $12.8 \%$ (Hastings et al. 2009) with 1950-1980 being the greatest rate of change. Today, NADP sites record rising $\mathrm{Nr}$ deposition in Wyoming that is composed of one third ammonium $\left(\mathrm{NH}_{3}\right)$. NADP passive sampling is known to underestimate ammonium concentrations because $\mathrm{NH}_{3}$ can volatilize during snow melt (Nanus 2003) and particulate $\mathrm{NH}_{3}$ formation in the atmosphere with nitrate, sulphate and hydrochloric acids are not captured in wet fall (Clarisse et al. 2009). Remote sensing of $\mathrm{NH}_{3}$ (Clarisse et al. 2009) has recently identified global hot spots, and an area of concern is the Snake River Valley, Idaho, approximately $150 \mathrm{~km}$ upwind from GRTE (Clarisse et al. 2009). The need to assess lacustrine sedimentary $\delta^{15} \mathrm{~N}$ signatures in GRTE is great because of the vulnerability to atmospheric deposition of depleted $\delta^{15} \mathrm{~N}$ DIN.
Trends in water quality data can also provide a measure of $\mathrm{Nr}$ impacts. $\mathrm{Nr}$ deposition is known to impact terrestrial catchments, such that $\mathrm{N}$ deposition can become in excess of plant and microorganism uptake and lead to soil $\mathrm{N}$ saturation, acidification and nitrification (MacDonald et al. 2002, Rogora 2007). The result is export of nitrate to the surface waters, where rates of nitrification and $\mathrm{N}$ mineralization are enhanced by increased atmospheric temperatures (Rogora 2007, Baron et al. 2009). Nitrate leaching is strongly dependant on the amount of atmospheric $\mathrm{Nr}$ deposition and associated with local sulphate deposition, slope, bedrock geology and latitude (Dise et al. 1998). Changes in lake and precipitation chemistry were measured in several western parks in 1985 and again in 1999 (Clow 2003). Results indicated that sulphate concentrations, like sulphate emissions, had declined from 1985 to 1999, while nitrate concentrations rose with $\mathrm{Nr}$ atmospheric loading in lakes across Montana, Wyoming and Colorado. Records from this study, however, included only one site in GRTE and there were no trends for that site. Here we present water chemistry from a suite of eight lakes to establish the current sulphate and nitrate concentrations.

Reactive $\mathrm{N}$ impacts a number of autotrophic organisms, although diatoms are the primary marker organism because of their preservation in sediments. Increasingly, diatoms associated with human activities are entering new aquatic systems and resulting in dramatic ecosystem change (Kociolek and Spaulding 2002, Kociolek and Spaulding 2000). Diatoms in lake sediments have been shown to be both responsive to environmental change and to be among the first organisms affected by chemical change (Douglas et al. 1994, Internandi et al. 1999, Ruhland et al. 2008, Pientz and Smol 1993, Hall and Smol 1996, Anderson et al. 1995). In the 14,000 year record from Sky Pond (Rocky Mountain NP), diatom assemblages reflected the pre-industrial period until gradual anthropogenically-induced change during 1950-1970 and a dramatic shift post-1970 towards mesotrophic species (Wolfe et al. 2003, Harper 1990), specifically the diatom Asterionella formosa Hassall. The dominance of this species has been associated with human settlement and lake eutrophication, but is not associated with acidification (Anderson et al. 1995, Harper 1990). Investigation of the physiological responses of $A$. formosa and Fragilaria crotonensis Kitton has revealed a unique growth response in high elevation western lakes as compared to more temperate lakes (Saros et al. 2005). While these two species are common in fairly nutrient rich temperate lakes, their abundance in low conductivity waters showed 
specific nitrogen requirements. In a number of experimental treatments, both $A$. formosa and $F$. crotonensis responded strongly to nitrogen enrichment, with no response to phosphorus enrichment alone (Saros et al. 2005, McKnight et al. 1990). Sediment reconstructions from eight lakes surveyed across the Beartooth Absaroka Wilderness and southern Rocky Mountains all showed increases in $A$. formosa or $F$. crotonensis, or both, after approximately 1950 due to atmospheric $\mathrm{Nr}$ loading (Saros et al. 2003, Saros et al. 2010). The increased deposition of $\mathrm{Nr}$ may be causing a nutrient imbalance. Elevated water column total nitrogen to total phosphorus (TN:TP) (Elser et al. 2009, Elser et al. 2009a) or DIN:TP ${ }^{9}$ ratios were found to be strongly related to regional $\mathrm{Nr}$ deposition trends across the United States, Norway and Sweden. Our research posits the question whether a shift from $\mathrm{N}$ to P-limitation may be a driving force in the dramatic ecological responses seen in $A$. formosa and $F$. crotonensis.

Separation of climate change and $\mathrm{N}$ deposition impacts can be problematic (Baron et al. 2009) and it is important to use multiple lines of evidence to understand changes in ecosystem processes. Studies in the European Alps have shown that high elevation lakes are sensitive to climate change and that changes in air temperature and $\mathrm{pH}$ are linked (Psnenner and Schmidt 1992, SommarugaWograth et al. 1997). Increases in $\mathrm{pH}$ with increasing temperature are thought to be the result of greater weathering rates of minerals or greater alkalinity production from microbial decomposition in lakes (Schindler 1986). Such processes might be acting to offset the impacts of acid deposition (Saros et al. 2003), because in some regions increases in atmospheric deposition of inorganic nitrogen have not increased concentrations of $\mathrm{N}$ or decreased $\mathrm{pH}$ in lake water. Experiments to examine relevant interactions of temperature and nutrient limitation on impacts of ultraviolet radiation in the Beartooth Mountains (Doyle et al. 2005) are informative. For all algal taxa, growth rates were higher at higher temperatures under each nutrient treatment and most growth rates were lower under UVR treatments. Therefore, we might expect that increases in lake temperature resulting from climatic change will amplify the diatom response to $\mathrm{Nr}$ deposition. In lakes of Rocky Mountain National Park, climatic changes were insufficient to explain the stratigraphic changes in $\delta^{15} \mathrm{~N}$ and diatom species composition (Wolfe et al. 2003).

Reconstructing historical values of $\mathrm{Nr}$ deposition in association with biological change over time allows definition of ecological thresholds at which $\mathrm{N}$ induces critical ecosystem impacts known as critical loads (Porter and Johnson 2007, Saros et al. 2010. Information on critical loads is important to federal land managers who are responsible for protection of resources in Class 1 areas. In Colorado, the current deposition of inorganic $\mathrm{N}$ is estimated to be an order of magnitude greater than historic values (Baron 2006), a finding that resulted in legislative action to reduce emissions in the state in 2010. Here we assess the paleolimnological record of nitrogen deposition and associated biotic response for the future development of a critical load for the GRTE region.

The purpose of this investigation is to infer the magnitude and history of $\mathrm{Nr}$ deposition and resulting impacts on aquatic biota in sensitive, high elevation lakes within the Greater Yellowstone Ecosystem. We analyzed the elemental chemistry of carbon, nitrogen, phosphorus, stable isotopic signature of $\delta^{13} \mathrm{C}$ and $\delta^{15} \mathrm{~N}$ and the diatom community composition to reconstruct the paleolimnology of seven Grand Teton National Park lakes that span a gradient of $\mathrm{N}: \mathrm{P}$ ratios. A central focus of our work is to determine the interaction of nitrogen deposition and climate change in these sites. In this study we will evaluate the range alternative explanations for observed changes in the paleolimnological record.

\section{STUDY AREA}

Grand Teton National Park is located in northwest Wyoming and is a designated Class I protected area, as part of the Greater Yellowstone Ecosystem. The Teton Mountain Range covers nearly half of the 310,000 acres of the national park, with many of the peaks over 3,000 $\mathrm{m}$ in elevation. Most of the high elevation lakes formed in glacially scoured basins. The underlying geology is predominately granite, gneiss and schist with veins of volcanic intrusions. Moraine deposits date from the Pinedale glaciation (Love 2007). We sampled eight lakes (Table 1) within three adjacent watersheds (Jenny Lake, Leigh Lake and Bradley Lake watersheds).

High elevation lakes were selected based on an evaluation of the geomorphology and bathymetry for favorable preservation of lacustrine deposition. Study lakes include Grizzly, Holly, Whitebark Moraine Pond (unnamed on USGS maps), Ramshead, Lake of the Crags, Delta, Amphitheater and Surprise. Water chemistry and sediment cores were sampled at a central location of each basin from an inflatable raft in July and August, 2010. Each lake was surveyed with a depth finder along three 
transects to assess the deepest point. Maximum lake depth ranged from 3.7 to $19.1 \mathrm{~m}$. Water samples were collected from three depths: surface $(0.3 \mathrm{~m})$, middepth (2-3 m) and deep (1 $\mathrm{m}$ from bottom) for a suite of water chemistry.

\section{$\uparrow \quad$ METHODS}

Water samples were collected in DI-rinsed $125 \mathrm{~mL}$ and $250 \mathrm{~mL}$ Nalgene bottles and glass amber bottles (for dissolved organic carbon, DOC). Samples for dissolved constituents were filtered on site through a $0.7 \mu \mathrm{m}$ Whatman ${ }^{\circledR} \mathrm{GF} / \mathrm{F}$ filter. Samples were kept refrigerated or frozen before transport to the Kiowa Environmental Chemistry Lab (INSTAAR, University of Colorado Boulder). Cations were measured with a flame atomic absorption spectrometer (Perkin Elmer AAnalyst 200) ammonium with a fluorescence detection plate reader (BioTeck Synergy ${ }^{\mathrm{TM}}$ 2) nitrate and silica with an automated chemical analyzer using continuous flow analyses (OI Analytical Flow Solution ${ }^{\circledR}$ IV) anions with ion chromatography using a Metrohm 761 Compact IC, total dissolved phosphorus and ortho-phosphate with colorimetric analyses using the flow injection analyzer (Lachat QC 8000 FIA) and organic carbon and total dissolved nitrogen using combustion catalytic oxidation with a non-dispersive infrared gas analyzer (Shimzadzu TOC-VCSN).

\section{Coring and sediment chronology}

Sediments were collected from the deepest point in each basin with a modified Kajak-Brinkhurst coring device (Glew 1989), fitted with a 3" diameter clear polycarbonate core tube. Short sediment cores were successfully recovered from all lakes, but Lake of the Crags. Upon examination of the visual stratigraphy and confirmation of clear sediment-water interface, cores were extruded on site at increments of $0.25 \mathrm{~cm}$ from surface sediments to $10 \mathrm{~cm}, 0.5 \mathrm{~cm}$ increments from 10 to $20 \mathrm{~cm}$ and $1 \mathrm{~cm}$ increments from 20 to core end. Core sections were bagged in labeled Whirlpak bags and refrigerated until delivery to the Sediment Processing Lab (INSTAAR, University of Colorado Boulder). In the lab, sediment samples were weighed, freeze dried and archived in glass vials.

Radiometric dating of the ${ }^{210} \mathrm{~Pb}$ isotope from the uranium decay series in sediments was conducted using the granddaughter of ${ }^{210} \mathrm{~Pb},{ }^{210} \mathrm{Po} .{ }^{210} \mathrm{~Pb}$ activity was measured from a subsample of 0.1 to $5 \mathrm{~g}$ that had been sieved with a $100 \mu \mathrm{m}$ mesh screen, pre-weighed into plastic $50 \mathrm{~mL}$ centrifuge vials and analyzed for
${ }^{210} \mathrm{~Pb}$ at the MyCore Scientific lab using alpha spectrometry (Appleby and Oldfield 1978). In samples that were not analyzed for ${ }^{210} \mathrm{~Pb}$ activity, a linear interpolation was used in order to calculate sedimentation rates and chronology.

Sedimentation rates $\left(\mathrm{g} \mathrm{m}^{-2} \mathrm{yr}^{-1}\right)$ were calculated from the cumulative dry mass $\left(\mathrm{g} \mathrm{m}^{-2}\right)$ multiplied by the decay constant $\left(\lambda \mathrm{yr}^{-1}\right)$ divided by the measured background activity ${ }^{210} \mathrm{~Pb}\left(\mathrm{~Bq} \mathrm{~g}^{-1}\right)$. Chronology was established using the constant rate of supply (CRS) model of ${ }^{210} \mathrm{~Pb}$ accumulation where ${ }^{210} \mathrm{~Pb}$ activity is allowed to vary with respect to decay over time and with changes in sediment accumulation rate (Appleby and Oldfield 1978).

\section{Diatom analysis}

Diatom slide preparation was conducted using $5 \mathrm{mg}$ dry sediment digested in $30 \%$ hydrogen peroxide solution and placed in a hot water bath for 2 days. Sediments were rinsed with de-ionized water and centrifuged, repeating until the solution measured neutral pH (Battarbee et al. 2001). A 0.4 to $1 \mathrm{~mL}$ aliquot of Polybead $\AA 4.5 \mu \mathrm{m}$ polystyrene microspheres at concentration $2.5 \times 10^{6}$ spheres $\mathrm{mL}^{-1}$ was added to each diatom digestion. These diatom slurries were pipetted onto glass cover slips, dried overnight and mounted using Zrax mounting medium. Alternate sediment sections were chosen for enumeration with a minimum of 300 diatoms counted along a transect, using an Olympus Vanox microscope equipped with differential interference contrast optics and a 1.3 NA 100X oil-immersion objective. Diatom concentrations were calculated based on the ratio of microspheres to diatom valves in each 300 valve count (Battarbee 1973). Diatom species identifications were based on taxonomic literature that included several volumes (Patrick and Reimer 1966, 1975, Antonaides et al. 2009, Krammer and Lange-Bertalot, 1985, 1986, 1988, 1991, 2000, 2004) and primary literature. Several of the taxa encountered are presented in detail with light and scanning electron micrographs (Spaulding et al. 2011).

\section{Sediment biogeochemistry}

Sediment stable isotopic composition was measured on bulk matter, weighed into tin capsules and submitted to the University of California Davis Stable Isotope Facility. Stable isotopes ${ }^{13} \mathrm{C}$ and ${ }^{15} \mathrm{~N}$ were analyzed with a PDZ Europa ANCA-GSL elemental analyzer interfaced with a PDZ Europa 2020 isotope ratio mass spectrometer (Sercon Ltd., Cheshire, UK). The $\delta^{13} \mathrm{C}$ values in each sediment 
core were corrected for the Seuss effect, which is the modeled depletion of atmospheric $\delta^{13} \mathrm{C}$ values due to accelerated rates of fossil fuel burning during industrialization (Verburg 2006).

\section{$\uparrow \quad$ Preliminary ReSUlts}

Lake water was circumneutral and oligotrophic with low conductivity, ion and nutrient concentrations. Transparency in most lakes was very high, except for Delta Lake, which was turbid from suspended glacial flour. Both Grizzly and Holly lakes support fish (Stephen 2007) and are known to have been stocked with Yellowstone cutthroat trout, Oncorhynchus clarkia bovieri, in the early $20^{\text {th }}$ century (Hazzard 1933). The other lakes are considered to lack fish (Stephens 2007), although three brook trout, Salvelinus fontinalis, were captured during a gill net survey of Ramshead Lake in 1994. Since that time, however, fish have not been reported.

A latitudinal gradient in conductivity (linear regression $\left.r^{2}=0.79\right)$ and ANC $\left(r^{2}=0.89\right)$ is present from Grizzly Lake to the north to Surprise Lake to the south $\left(15.6-6.4 \mu \mathrm{S} \mathrm{cm}^{-1}\right.$ and $119-50 \mu \mathrm{eq} \mathrm{L} \mathrm{L}^{-1}$, respectively). The same $\mathrm{N}-\mathrm{S}$ gradient exists in calcium $\left(r^{2}=0.81\right)$ and sulphate $\left(r^{2}=0.64\right)$ concentrations from Grizzly to Surprise Lake (48.4 $15.2 \mu \mathrm{mol} \mathrm{L}^{-1}$ and $10.6-3.3 \mu \mathrm{mol} \mathrm{L}^{-1}$, respectively). Silica concentrations have a weaker N-S trend $\left(r^{2}=0.46\right)$, with concentrations measuring $13.9-43$ $\mu \mathrm{mol} \mathrm{L}{ }^{-1}$.

Essential growth nutrients, $\mathrm{N}$ and $\mathrm{P}$ lacked a latitudinal trend, but showed other patterns. The total $\mathrm{N}$ concentrations (mean $7.6 \pm 3.2 \mu \mathrm{mol} \mathrm{L}^{-1}$ ) amongst lakes varied more than the total $\mathrm{P}$ concentrations $\left(0.11 \pm 0.025 \mu \mathrm{mol} \mathrm{L}^{-1}\right)$. The relative proportion of $\mathrm{N}$ constituents $\left(\mathrm{NH}_{4}{ }^{+}, \mathrm{NO}_{3}{ }^{-}\right.$, particulate $\mathrm{N}$ and dissolved organic nitrogen DON) showed a range of speciation Figure 1). The highest TN values were in glacial-fed Delta Lake, with over $95 \%$ in the form of $\mathrm{NO}_{3}{ }^{-}$. In contrast, $85 \%$ of the TN in Whitebark Moraine Pond was in the form of DON. There is a trend with DOC and TP showing a positive linear relationship with the catchment area to surface area ratio at $r^{2}=0.76$ and 0.63 respectively. The highest TP concentrations were in Whitebark Moraine Pond, largely composed of DOP. The lowest TP concentrations were in Amphitheater Lake, composed predominantly of particulate, bound $\mathrm{P}$.

TN:TP (molar) ratios can be used to characterize the relative availability of $\mathrm{N}$ to $\mathrm{P}$ in the basin (Figure 1). When $\mathrm{N}$ availability is high, phytoplankton productivity in freshwater bodies can become P limited. In North America, TN:TP values above 50 (molar) (Elser et al. 2009, Guildford and Hecky 2000) were found to be P limited systems. Based on those findings, nearly all lakes in GRTE are P-limited, except Holly Lake. Bergstrom (2010) found that DIN:TP (mass) ratios had better predictability than TN:TP ratios with values above 3.4 having a $75 \%$ probability of predicting $\mathrm{P}$ limitation during fertilization experiments. Since DON is the dominant species of $\mathrm{N}$ in White Bark Moraine Pond and Surprise Lake, the DIN:TP values are low ( 3.4, Figure 1) and potentially N-limited during the post-snowmelt season in July and August.

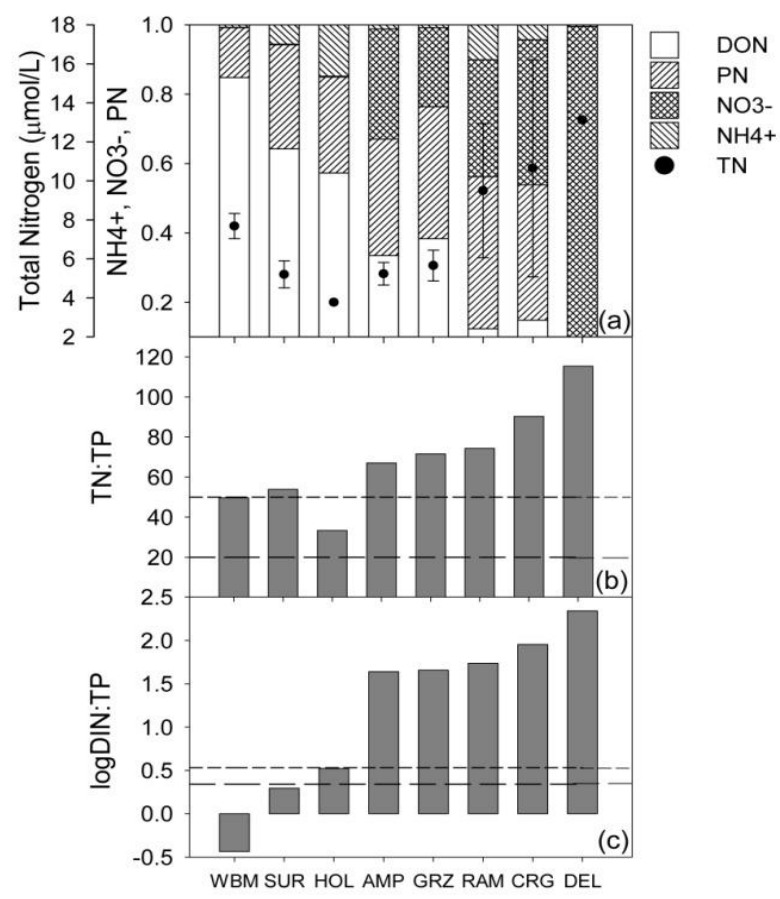

Figure 1. Total nitrogen speciation for each of the eight sampling sites in the Grand Teton National Park, WY. (a) Total nitrogen on the outside left vertical axis is represented as a proportion of the $\mathrm{N}$ species (from the top down) ammonia (NH4+), nitrate (NO3-), particulate $\mathrm{N}(\mathrm{PN})$ and dissolved organic $\mathrm{N}$ (DON). (b) Total nitrogen (TN) to total phosphorus (TP) molar ratios for each of the GRTE lakes, the long dashed line at 20 denotes the threshold below which phytoplankton were not found to be $\mathrm{P}$ deficient and the short dashed line at 50 denotes phytoplankton above which $\mathrm{P}$ deficiency was found in freshwater lakes (Guildford and Hecky 2000). (c) Dissolved inorganic nitrogen (DIN) to TP mass ratios are presented on a $\log$ scale with $\log 2.2$ denoting $50 \%$ probability of $\mathrm{P}$ limitation and $\log 3.4$ denoting $75 \%$ probability of $\mathrm{P}$ limitation (Bergström 2010).

\section{Chronology}

Sediment records could not be recovered from Lake of the Crags, and thus paleolimnological reconstructions were carried out on the seven remaining lakes. Sediment chronology was based on 
the CRS model applied to the ${ }^{210} \mathrm{~Pb}$ activity profiles (Figure 2). Overall, the background ${ }^{210} \mathrm{~Pb}$ activities from the GRTE lakes were considerably high (mean $0.18 \mathrm{~Bq} \mathrm{~g}^{-1}$ ), ten times what may be expected of an oligotrophic lake (Larder per. com.). Grizzly Lake had the highest ${ }^{210} \mathrm{~Pb}$ activity at $0.57 \mathrm{~Bq} \mathrm{~g}^{-1}$. High background levels were likely the result of ${ }^{226} \mathrm{Ra}$ and ${ }^{238} \mathrm{U}$ in the rock and soils within the catchment or from high ${ }^{222} \mathrm{Rn}$ in groundwater (Norton et al. 1985). The background measures were also more variable between sites, but this is to be expected if the radium is very high (Norton et al. 1985). In Holly Lake, sediment ${ }^{210} \mathrm{~Pb}$ did not measure background levels, so background values from Whitebark Moraine Pond were used as both lakes share similar levels of ${ }^{210} \mathrm{~Pb}$ activity.

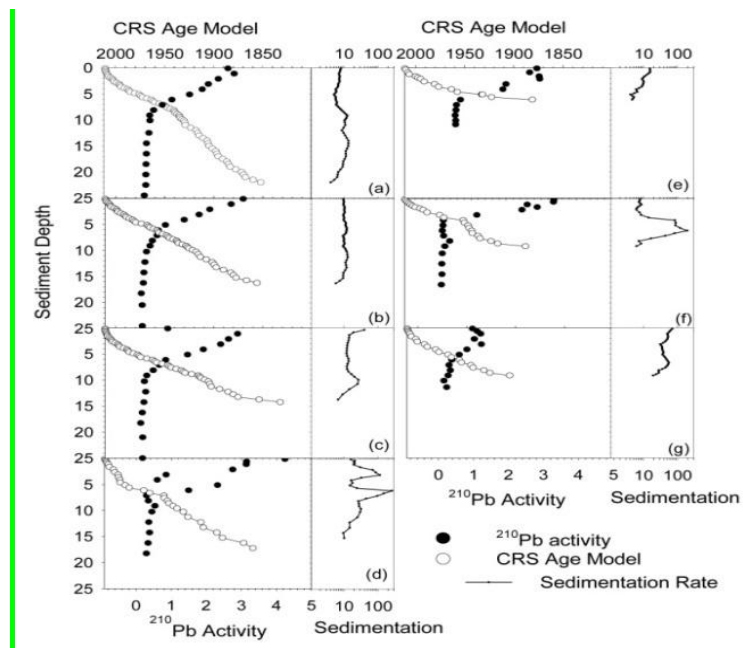

Figure $2 .{ }^{210} \mathrm{~Pb}$ activity decay profiles $\left(\bullet, \mathrm{Bq} \mathrm{g}^{-1}\right)$, constant rate of supply CRS age model $(\mathrm{O}$, date) and sedimentation rate (line plot, $\mathrm{g} \mathrm{m}^{-2} \mathrm{yr}^{-1}$ ) for sediment cores recovered from (a) Whitebark Moraine Pond, (b) Surprise, (c) Amphitheater, (d) Holly, (e) Grizzly, (f) Ramshead, and (g) Delta Lakes during July and August 2010 from Grand Teton National Park, WY. Note the sedimentation rates are shown in log scale plot.

Sedimentation rates (Figure 2) were all very low and consistent with similar studies of high alpine lakes (Norton et al. 1985, Brenner et al. 2004). Sedimentation rates in Whitebark Moraine Pond and Surprise Lakes remained relatively unchanged as compared to the large sedimentation events that occurred in Ramshead and Holly Lakes or the trend in rising sedimentation rates in Grizzly (since 1994 ) and Delta $(\sim 1993)$ Lakes.

\section{Diatom community structure}

All diatom assemblages from GRTE lakes were dominated by benthic taxa with varying relative abundances that were sorted along the range of $\mathrm{N}: \mathrm{P}$ values from lake water chemistry from Whitbark
Moraine Pond to Ramshead Lake (Figure 3). Delta Lake did not have an enumerable preserved diatom fossil record. Whitebark Moraine Pond contained a very high abundance of Staurosirella pinnata (Ehrenberg) Williams et Round, Staurosira construens var. venter (Ehrenberg) Hamilton, and to a lesser extent Pseudostaurosira brevistriata (Grunow in Van Heurck) Williams et Round. Amphitheatre and Surprise Lakes share a similar diatom assemblage likely because of the hydrological connection from the outlet at Amphitheater Lake, which feeds into Surprise Lake downstream. Both lakes have a high number of diatom taxa represented because percent abundances are $<10 \%$ that include Stauroforma exiguiformis (Lange-Bertalot) Flower et al. Aulacoseira nivalis (W. Smith) English et Potapova and a diversity of monoraphid Psammothidium species.

Aulacoseira nivalis (W. Smith) English et Potapova and Discostella stelligera (Cleve et Grunow) Houk et Klee were one of a few planktonic taxa that were present in greater relative abundances. Aulacoseira nivalis was only present in Amphitheatre and Surprise Lakes at 6.8 to $8.7 \%$ abundance and < $1 \%$ at all other sites. Discostella stelligera (Cleve et Grunow) Houk et Klee, was represented at 15 to 40 $\%$ relative abundance in Holly, Grizzly, and Ramshead Lakes.

Fragilaria crotonensis and Asterionella formosa are mesotrophic planktonic diatoms found in many anthropogenically eutrophied lakes. Fragilaria crotonensis was present in Surprise, Amphitheater and Grizzly Lakes at $<1 \%$ and in Ramshead Lake at $6.8 \%$ total core abundance. Fragilaria crotonensis was found in sediments dating before 1850 with no discernable population trend. Asterionella formosa was present only in sediment samples from Holly Lake during $\sim 1985$ to 2010, however relative abundance does not exceed 3\%. Overall, diatom community composition does not indicate a shift towards planktonic mesotrophic taxa, but rather a relatively unaltered benthic diatom community composition during the past 150 years and earlier.

\section{Sediment geochemistry and stable isotopes}

Comparison amongst the concentrations of phosphorus, nitrogen and carbon and the $\mathrm{C}: \mathrm{N}$ (molar), $\delta^{13} \mathrm{C}$ and $\delta^{15} \mathrm{~N}$ stable isotopic composition of each sediment core (Figures 3 and 4) showed that in all sediment cores C:N (except Delta Lake) and $\delta^{15} \mathrm{~N}$ decline. $\delta^{15} \mathrm{~N}$ plots followed a trend in depletion in all lakes, from pre-industrial values of up $2.7 \%$ to surface sediments of $-2.2 \%$, an average $\delta^{15} \mathrm{~N}$ 

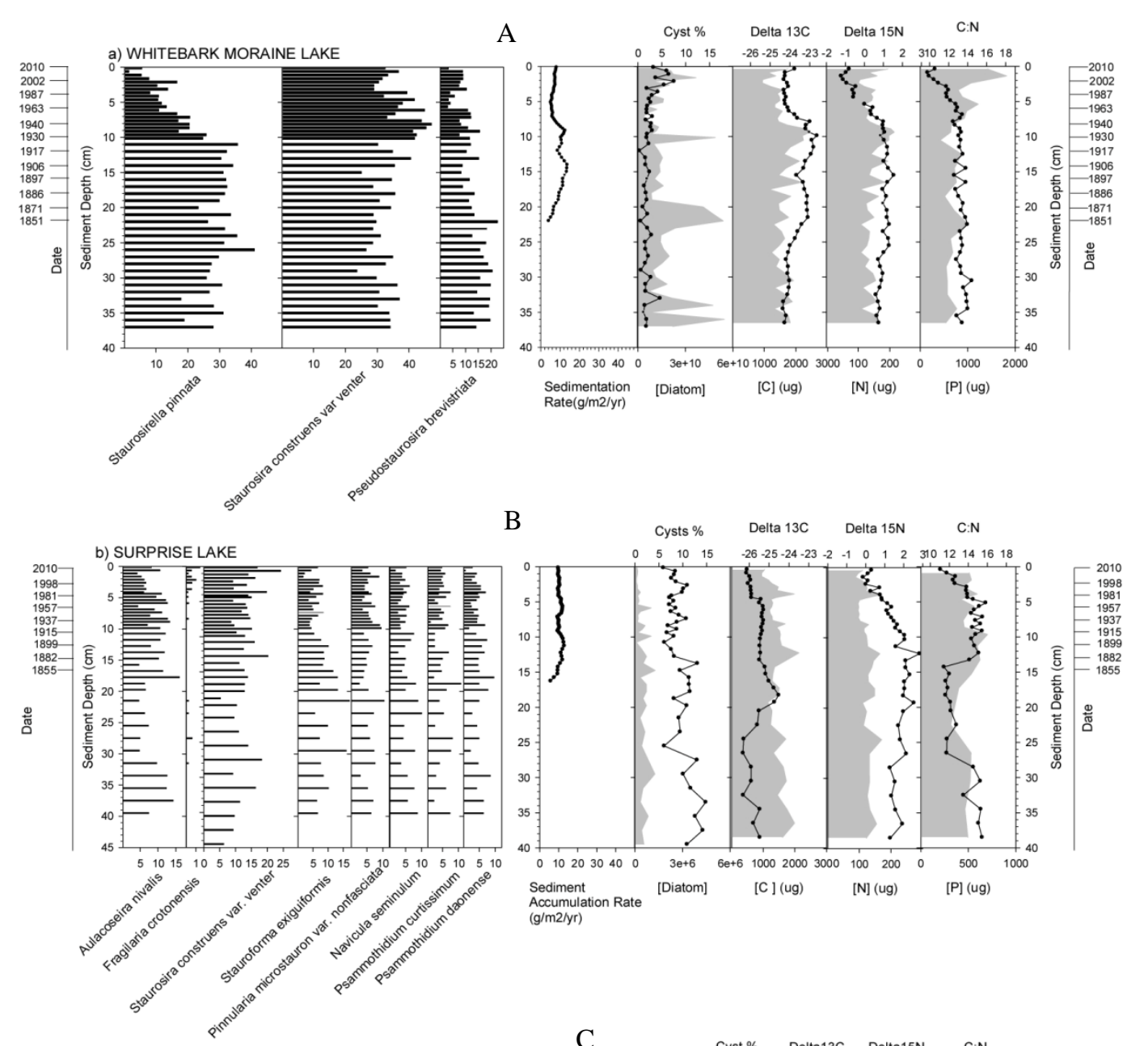

B
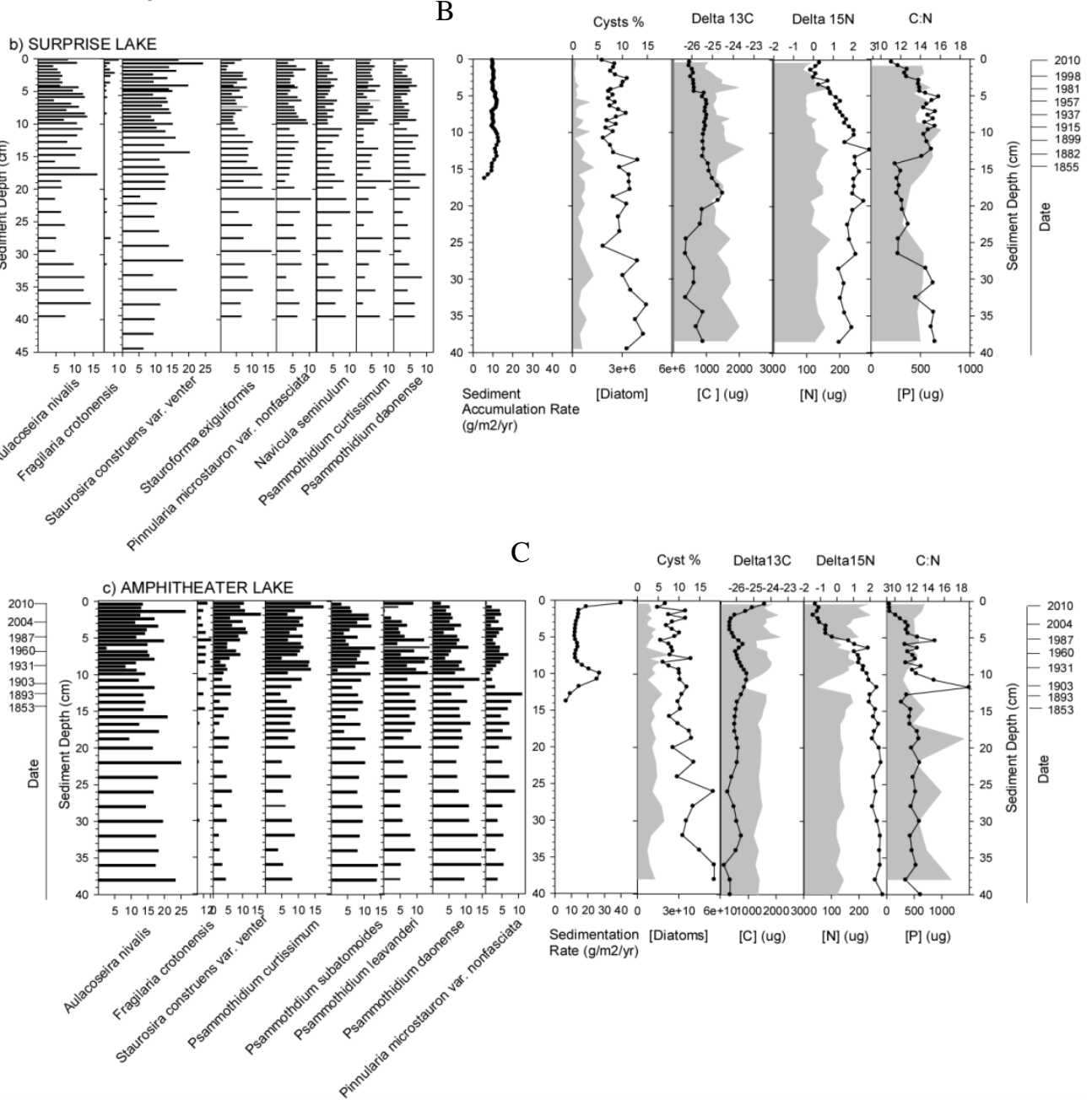

Figure 3. Diatom stratigraphies and biogeochemistry from A) Whitebark Moraine, B) Surprise and C) Amphitheater Lakes from Grand Teton National Park, WY. Diatom relative abundances from preserved sediment samples (bar charts), sedimentation rates $(\bullet)$, diatom concentrations (grey area plot), \% cyst abundance $(\bullet)$, carbon concentrations, (area) $\delta^{13} \mathrm{C}(\bullet$ ) nitrogen concentrations (area) $\delta^{15} \mathrm{~N}(\bullet)$ phosphorus concentrations (area) and C:N molar ratios $(\bullet)$. 


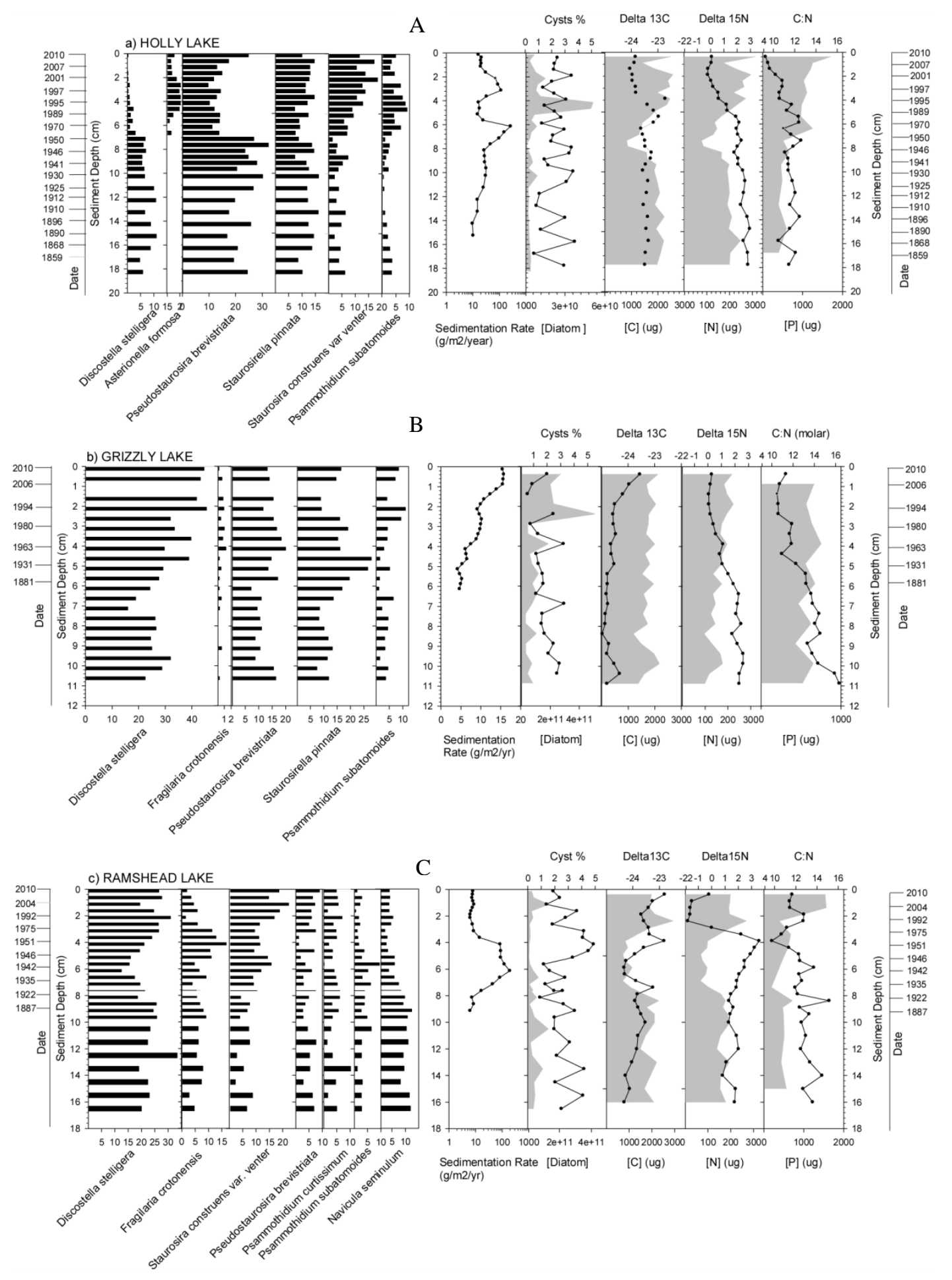

Figure 4. Diatom stratigraphies and biogeochemistry from A) Holly, B) Grizzly and C) Ramshead Lakes from Grand Teton National Park, WY. Diatom relative abundances from preserved sediment samples (bar charts), sedimentation rates $(\bullet)$, diatom concentrations (grey area plot), \% cyst abundance $(\bullet)$, carbon concentrations, (area) $\delta^{13} \mathrm{C}\left(\bullet\right.$ ) nitrogen concentrations (area) $\delta^{15} \mathrm{~N}$ $(\bullet)$ phosphorus concentrations (area) and C:N molar ratios $(\bullet)$. 
depletion $2.2 \%$ during the past 150 years. At the same time, there was also a coincident decline in $\mathrm{C}: \mathrm{N}$ ratios from an average of 13.0 to 10.5 starting around 1960 until present. C:N ratios in Delta lake were not discernable. The large fluctuations in inorganic deposition in Ramshead Lake that increased sedimentation rates during $1942-1951$ appear to have impacted the biogeochemical trends.

Sedimentary concentrations of $\mathrm{P}, \mathrm{C}$ and $\mathrm{N}$ varied considerably amongst GRTE lakes, whereas nutrient stoichiometry was consistent. Concentrations of $\mathrm{P}$ increased in most lakes but Amphitheater and Grizzly Lakes, while concentrations of $\mathrm{C}$ and $\mathrm{N}$ have gradually increased in Holly, Amphitheater, Grizzly, Ramshead and Delta Lakes over time. Sedimentary molar ratios of $\mathrm{C}: \mathrm{P}$ and $\mathrm{N}: \mathrm{P}$ were on average $7.3 \pm$ 1.0 and $0.58 \pm 0.09$ respectively for all GRTE lake sediments except Delta Lake $(1.6 \pm 0.5$ and $0.18 \pm$ $0.05)$. Sedimentary ratios were an order of magnitude lower than water column measures and do not suggest $\mathrm{P}$ limitation.

The bulk organic matter stable isotopic composition of $\delta^{13} \mathrm{C}$ Seuss corrected values showed little change in Whitebark Moraine Pond, Surprise and Holly Lakes but an enrichment trend in Amphitheater after 2004, Grizzly 1994, Ramshead $\sim 1995$ and Delta Lake 1938 .

\section{$\uparrow \quad$ MANAGEMENT IMPLICATIONS}

The impact of this regional $\mathrm{Nr}$ deposition does not appear to affect each lake similarly, but sediment records follow a series of ecological impacts along a continuum of nutrient enrichment. This response continuum starts from a shift in the relative availability of growth limiting nutrients ( $N$ and $\mathrm{P}$ ) to greater primary production, accelerated rates of primary production and increased sedimentation rates. In many other alpine lakes, benthic communities were replaced by planktonic mesotrophic taxa, such as Asterionella formosa, as nutrient enrichment can result in benthic habitat loss due to reduced light penetration and self-shading that shift the ecological functioning of an aquatic system (Anderson 1995, Nanus et all. 2009, Hobbs et al. 2010, Steward, Lamoureux and Finnery 2008).

All seven GRTE lakes show coherent influence of anthropogenic $\mathrm{N}$, based on $\delta^{15} \mathrm{~N}$ signatures, despite differential speciation of $\mathrm{N}$ in the water chemistry of each lake. This declining $\delta^{15} \mathrm{~N}$ sediment signature is pervasive and evidence strongly suggests $\mathrm{Nr}$ deposition is the primary environmental threat to these remote high alpine lakes. This coherent $\delta^{15} \mathrm{~N}$ trend also supports that alpine lakes from the GRTE are an excellent source of long-term atmospheric loading records and could be useful in reconstructing other atmospheric pollutants, such as $\mathrm{Pb}, \mathrm{Hg}$ and persistent organic pollutants.

\section{ACKNOWLEDGEMENTS}

Special thanks to Sue O’Ney, Grand Teton National Park and Ellen Porter, Tamara Blett and Terry Svalberd of the National Park Services Air Resources Division who helped facilitate research in the Grand Teton National Park through funding support (NPS award \#119720) and assisting with field logistics. We thank Jack Cornett and Janice Lardner of MyCore Scientific for ${ }^{210} \mathrm{~Pb}$ analyses and interpretation; Joy Matthews of UC Davis Stable Isotope Facility; and Christine Siebold, Holly Shuss and Holly Hughes of the Kiowa Lab. We are grateful to our field volunteers Heather Mosher, Katie Williams, Brooke Osbourne, Julia Spencer, Chad Whaley, Lindsey Mills and Ed Mellander who helped transport sampling equipment to remote sites. We acknowledge laboratory assistance at University of Colorado, INSTAAR, by Anna Hermann and Wendy Roth who helped process and analyze sediment samples. Discussions with Janice Brahney and Ashley Ballantyne who helped inform our interpretations.

*Any use of trade names is for descriptive purposes only and does not imply endorsement by the U.S. Government.

\section{$\uparrow \quad$ LiTERATURE CiTED}

Anderson NJ, Renber I, Segerstrom U. 1995. Diatom production responses to the development of early agriculture in a boreal forest lakecatchment (Kassjon, northern Sweden). Journal of Ecology. 83:809-822.

Antoniades D, Hamilton PB, Douglas MSV, Smol JP. 2008. Diatoms of North America: The freshwater floras of Prince Petrcik, Ellef Ringnes and northern Ellesmere Islands from the Canadian Arctic Archipelago. Iconographia Diatomologica. 17.

Appleby PG, Oldfield F. 1978. The calculation of lead-210 dates assuming a constant rate of supply of unsupported $21 \mathrm{~Pb}$ to the sediment. Catena 5:1-8. 
Baron JS, Schmidt TM, Hartman MD. 2009. Climateinduced changes in high elevation stream nitrate dynamics. Global Change Biology. 15:1777-1789.

Baron JS. 2006. Hindcasting nitrogen deposition to determine an ecological critical load. Ecological applications : a publication of the Ecological Society of America. 16:433-9.

Baron JS, Rueth HM, Wolfe AM, Nydick KR, Allstott EJ, Minear JT, Moraska B. 2000. Ecosystem Responses to Nitrogen Deposition in the Colorado Front Range. Ecosystems. 3:352-3682000.

Battarbee RW, Cameron NG, Golding P, Brooks J, Switsur R, Harkness D, Appleby P, Oldfield F, Thompson R, Monteith DT, McGovern A. 2001. Evidence for Holocene climate variability from the sediments of a Scottish remote mountain lake. Journal of Quaternary Science. 16:339-346.

Battarbee RW. 1973. A new method for the estimation of absolute microfossil numbers, with reference especially to diatoms. Limnology and Oceanography. 18:647653(1973).

Brenner M, Schelske CL, Kenney WF. 2004. Inputs of dissolved and particulate ${ }^{236} \mathrm{RA}$ to lakes and implications for ${ }^{210} \mathrm{~Pb}$ dating recent sediments. Journal of Paleolimnology. 32:5366.

Bergström A-K. 2010.The use of TN:TP and DIN:TP ratios as indicators for phytoplankton nutrient limitation in oligotrophic lakes affected by $\mathrm{N}$ deposition. . 72:277-281.

Burns DA. 2003. Atmospheric nitrogen deposition in the Rocky Mountains of Colorado and southern Wyoming — a review and new analysis of past study results. Science 37: 921-932.

Clarisse L, Clerbaux C, Dentener F, Hurtmans D, Coheur P. 2009. Global ammonia distribution derived from infrared satellite observations. Nature Geoscience. 2:479-483.

Clow DW. 2003. Changes in the chemistry of lakes and precipitation in high-elevation national parks in the western United States, 19851999. Water Resources Research. 39.
Dise NB, Matzner E, Forsius M. 1998. Evaluation of organic horizon $\mathrm{C}: \mathrm{N}$ ratio as an indicator of nitrate leaching in conifer forests across Europe. Environmental Pollution. 102:453456.

Douglas MS, Smol JP, Blake WJ. 1994. Marked post-18th century environmental change in High-Arctic ecosystems. Science. 266:416419.

Doyle SA, Saros JE, Williamson CE. 2005. Interactive effects of temperature and nutrient limitation on the response of alpine phytoplankton growth to ultraviolet radiation. Limnology and Oceanography. 50:13621367.

Elser JJ, Anderson T, Baron JS, Bergstom A, Jansson M, Kyle M, Nydick KR, Steger L, Hessen DO. 2009. Shifts in lake N:P stoichiometry and nutrient limitation driven by atmospheric nitrogen deposition. Science 326:835-7.

Elser JJ, Kyle M, Steger L, Nydick KR, Baron JS. 2009a. Nutrient availability and phytoplankton nutrient limitation across a gradient of atmospheric nitrogen deposition. Ecology. 90:3062-73.

Fenn ME, Haeuber R, Tonnesen G, Baron JS, GrossmanClark S, Hope D, Jaffe DA, Copeland S, Geiser L, Rueth HM, et al. 2003. Nitrogen Emissions, Deposition, and Monitoring in the Western United States. BioScience. 53:391.

Glew JR. 1989. A new trigger mechanism for sediment samplers. Journal of Paleolimnology 2:241-243.

Guildford SJ, Hecky RE. 2000. Total nitrogen, total phosphorus, and nutrient limitation in lakes and oceans: is there a common relationship. Limnology and Oceanography. 45:12131223.

Hall RI, Smol JP. 1996. Paleolimnological assessment of long-term water-quality changes in south-central Ontario lakes affected by cottage development and acidification. Canadian Journal of Fisheries and Aquatic Sciences. 53:1-17.

Harper MA. 1990. Did Europeans introduce Asterionella formosa (Hassall) into New 
Zealand. Proceedings of the 11th International Diatom Symposium. 480-484.

Hazzard JC, Hayter Crickmay C. Notes on the Cambrian rocks of the eastern Mohave Desert, California. University of California Press; 1933.

Hobbs WO, Telford RJ, Birks HJB, Saros JE, HAewinkel RRD, Perren BB, Sauinier-Talbot E, Wolfe AP. 2010. Quantifying recent ecological changes in remote lakes of North America and Greenland using sediment diatom assemblages. PloS one. 5:e10026.

Holland EA, Dentener F, Braswell BH, Sulzman JM. 1999. Contemporary and pre-industrial global reactive nitrogen budgets. Biogeochemistry. 46:7-43.

Interlandi SJ, Kilham SS, Theriot EC. 1999. Responses of phytoplankton to varied resource availability in large lakes of the Greater Yellowstone Ecosystem. Limnology and Oceanography 44:668-682.

Kociolek JP, Spaulding SA. 2002. Morphological Variation, Species Concepts, and Classification of an Unusual Fossil Centric Diatom (Bacillariophyta) From Western North America1. Journal of Phycology. 38: 821-833.

Kociolek JP, Spaulding SA. 2000. Freshwater diatom biogeography. Nova Hedwigia 71:223-241.

Krammer K Lange-Bertalot H. 1986. Bacillariophyceae. 1. Teil: Naviculaceae. In: Editors, Ettl H, Gerloff J, Heynig H, Mollenhauer D. Susswasserflora von Mitteleuropa, Band 2/1. Gustav Fisher Verlag, Jena. 876 pp.

Krammer K Lange-Bertalot H. 1988. Bacillariophyceae. 2. Teil: Bacillariaceae, Epithemiaceae, Surirellaceae. In: In: Editors, Ettl H, Gerloff J, Heynig H, Mollenhauer D. Ettl, Susswasserflora von Mitteleuropa, Band 2/2. Gustav Fisher Verlag, Jena.

Krammer K. Lange-Bertalot H. 1991. Bacillariophyceae. 3. Teil: Centrales, Fragilariaceae, Eunotiaceae. . In: Editors, Ettl H, Gerloff J, Heynig H, Mollenhauer E.. Süsswasserflora von Mitteleuropa. 2(3): 1-
576. Gustav Fisher Verlag, Stuttgart, Germany.

Krammer K Lange-Bertalot H. 2004. Bacillariophyceae 4. Teil: Achnanthaceae, Kritische Erganzungen zu Navicula (Lineolatae), Gomphonema Gesamtliteraturverzeichnis Teil 1-4 [second revised edition]. In: Editors, Ettl $\mathrm{H}$, et al., Suesswasserflora von Mitteleuropa. Spektrum Akademischer Verlad Heidelberg, $468 \mathrm{pp}$.

Krammer K, Lange-Bertalot H. 1991. Bacillariophyceae. 3. Teil: Centrales, Fragilariaceae, Eunotiaceae. . In Editors, Ettl H, Gerloff J., Heynig H, Mollenhauer D. Süsswasserflora von Mitteleuropa. 2(3): 1576. Gustav Fisher Verlag, Stuttgart, Germany.

Krammer K. Lange-Bertalot H. 2004. Bacillariophyceae 4. Teil: Achnanthaceae, Kritische Erganzungen zu Navicula (Lineolatae), Gomphonema Gesamtliteraturverzeichnis Teil 1-4 [second revised edition]. In: Editors, Ettl H, Gerloff J., Heynig $\mathrm{H}$, Mollenhauer D. Suesswasserflora von Mitteleuropa. Spektrum Akademischer Verlad Heidelberg, $468 \mathrm{pp}$.

Lafrancois BM, Nydick KR, Hohnson BM, Baron JS. 2004. Cumulative effects of nutrients and $\mathrm{pH}$ on the plankton of two mountain lakes. Ecology. 1165:1153-1165.

Love JD, Reed JC, Pierce KL.Creation of the Teton landscape: a geologic chronicle of Jackson Hole and the Teton Range. Jackson WY: Grand Teton Natural History Association. 2007.

McKnight DM, Smith RL, Bradbury JP, Baon JS, Spaulding S. 1990. Phytoplankton Dynamics in Three Rocky Mountain Lakes, Colorado, U.S.A. Arctic and Alpine Research. 22:264.

MacDonald JA, Dise NB, Matzner E, Armbruster M, Gunderon P, Forsius M. 2002. Nitrogen input together with ecosystem nitrogen enrichment predict nitrate leaching from European forests. Global Change Biology. 8:10281033. 
Naftz DL, Schuster PF, Johnson CA. 2011. A 50-year record of $\mathrm{NOx}$ and $\mathrm{SO} 2$ sources in precipitation in the Northern Rocky Mountains, USA. Geochemical transactions. $12: 4$.

Nanus L, Williams MW, Campbell DL, Elliott EM, Kendall C. 2008. Evaluating regional patterns in nitrate sources to watersheds in National Parks of the Rocky Mountains using nitrate isotopes. Environmental science and technology. 42:6487-93.

Nanus L, Campbell DH, Milliams MW. 2005. Sensitivity of Alpine and Subalpine Lakes to Acidification from Atmospheric Deposition in Grand Teton National Park and Yellowstone National Park Wyoming Scientific Investigations Report 2005 - 5023. Availible from UWSG, Denver CO 80225.

Nanus L. 2003. Atmospheric deposition maps for the Rocky Mountains. Atmospheric Environment 37:4881-4892.

Norton SA, Hess CT, Blake GM, Morrison ML, Baron J. 1985. Excess Unsupported 210Pb in Lake Sediment from Rocky Mountain Lakes: A Groundwater Effect. Canadian journal of fisheries and aquatic sciences. 42(7): 12491254.

Nydick KR, LaFrancois BM, Barton JS, Johnson BM. 2004. Nitrogen regulation of algal biomass, productivity, and composition in shallow mountain lakes, Snowy Range, Wyoming, USA. 1268:1256-1268.

Patrick R, Reimer CW. The Diatoms of the United States exclusive of Alaska and Hawaii, V. 1. Philadelphia. Monographs of the Academy of Natural Sciences of Philadelphia 13. 1966.

Patrick R, Reimer CW. 1975. The Diatoms of the United States, exclusive of Alaska and Hawaii, V. 2. Monographs of the Academy of Natural Sciences of Philadelphia 13.

Patrick R, Reimer CW. The Diatoms of the United States V2. Philadephia: Academy of Natural Sciences; 1975.

Pienitz R, Smol JP. 1993. Diatom assemblages and their relationship to environmental variables in lakes from the boreal forest-tundra ecotone near Yellowknife, Northwest Territories, Canada. Hydrobiologia. 269-270:391-404.

Porter E, Johnson S. 2007. Translating science into policy: using ecosystem thresholds to protect resources in Rocky Mountain National Park. Environmental pollution. 149:268-80.

Psenner R, Schmidt R. 1992. Climate-driven pH control of remote alpine lakes and effects of acid deposition. Nature. 356:781-783.

Rogora M. 2007. Synchronous trends in N-NO3 export from $\mathrm{N}$-saturated river catchments in relation to climate. Biogeochemistry. 86:251268.

Rühland KM, Paterson AM, Smol JP. 2008. Hemispheric-scale patterns of climate-related shifts in planktonic diatoms from North American and European lakes. Global Change Biology. 14:2740-2754.

Saros JE, Clow DW, Blett T, Wolfe AP. 2010. Critical Nitrogen Deposition Loads in Highelevation Lakes of the Western US Inferred from Paleolimnological Records. Water, Air, and Soil Pollution. 216:193-202.

Saros JE, Michel TJ, Interlandi SJ, Wolfe AP. 2005. Resource requirements of Asterionella formosa and Fragilaria crotonensis in oligotrophic alpine lakes : implications for recent phytoplankton community reorganizations. Earth. 1689: 1681-1689.

Saros JE, Interlandi SJ, Wolfe AP, Engstrom DR. 2003. Recent Changes in the Diatom Community Structure of Lakes in the Beartooth Mountain Range, U.S.A. Arctic, Antarctic, and Alpine Research. 35:18-23.

Seastedt TR, Bowman WD, Caine TN, McKnight D, Townsend A, Williams MA. 2004. The Landscape Continuum: A Model for HighElevation Ecosystems. BioScience. 54:111121.

Schindler DW. 1986. The significance of in-lake production of alkalinity. Water, Air, and Soil Pollution. 30:931-944.

Sommaruga-Wograth S, Koinig KA, Schmidt R, Sommaruga R, Tessadri R, Psenner R. 2007. 
Temperature effects on the acidity of remote alpine lakes. Nature. 387:64-66.

Spaulding SA, Lubinski DJ, Potapova M. 2010. Diatoms of the United States. http://westerndiatoms.colorado.edu Accessed on 17 October, 2012.

Stephens TJ. 2007. Inventory of fish in alpine lakes in Grand Teton National Park, Wyoming.

Stewart KA, Lamoureux SF, Finney BP. 2008. Multiple ecological and hydrological changes recorded in varved sediments from Sanagak Lake, Nunavut, Canada. Journal of Paleolimnology. 40:217-233.
Williams MW, Tonnessen K. 2000. A Critical Loads for Inorganic Nitrogen Deposition in the Colorado Front Range, USA. Ecological Applications. 10:1648-1665.

Williams MW, Davinroy T, Brooks PD. 1997. Organic and inorganic nitrogen pools in talus fields and subtalus water, Green Lakes Valley, Colorado Front Range. Hydrological Processes. 11:1747-1760.

Wolfe AP, Van Gorp AC, Baron JS. 2003. Recent ecological and biogeochemical changes in alpine lakes of Rocky Mountain National Park (Colorado, USA): a response to anthropogenic nitrogen deposition. Geobiology. 1:153-168.

Wolfe AP et al. (Forthcoming). Stratigraphic expressions of the Holocene-Anthropocene transition revealed in sediments from remote lakes. 